\title{
The Connection between Nautical Professional English and Basic English
}

\author{
Yuan Gao \\ Shandong Jiaotong University, Weihai, China
}

Keywords: basic English nautical professional English optimization convergence improvement

\begin{abstract}
This paper points out the necessity of the connection between basic English and professional English teaching in the current maritime colleges, and then puts forward some ideas about English convergence of the basic English and navigation majors in the analysis of the possibility of connecting the two.
\end{abstract}

\section{Basic English and professional English teaching management in maritime colleges}

The maritime profession itself is international, so the level of English is especially important for maritime students. At the same time, English is one of the basic skills required for higher vocational education. Therefore, the English level of students has become one of the standards reflecting the quality of maritime vocational and technical education. Since the end of November 1996, the Maritime English Test Group of the Department of Education of the Ministry of Communications has conducted English proficiency tests on the relevant maritime majors, all maritime colleges have strengthened the management of English teaching, and all maritime colleges have The English level raises higher requirements.

All maritime higher education institutions divide English teaching into two parts: basic English and professional English. Basic English and professional English teaching should complement each other. Basic English is the foundation of professional English, while professional English is the application and extension of basic English. Without a solid foundation of English knowledge, professional English teaching cannot be completed smoothly; at the same time, English, especially professional English, is an indispensable tool for practical navigation. Therefore, dealing with the relationship between the two in the teaching process to ensure their effective connection is an important way to help students improve their English.

\section{The current problems and the need to link basic English and professional English}

The current English teaching system in Chinese maritime colleges is the teaching mode of "Basic English + Professional English", but the basic English and professional English models are basically independent of each other, and there is no effective communication and integration. In maritime undergraduate colleges, basic English teaching is generally carried out in the first and second grades of the university, and the specialties are only placed in the first grade. The teachers who are engaged in basic English teaching are mainly to let undergraduate students pass the "English Level 4" and let the students pass the "English Application Ability Test". Therefore, to a large extent, the teaching is to cater to the examination, thus ignoring the students' application ability. Cultivate and develop. Under normal circumstances, students almost no longer spend time and energy to learn English after passing the exam. The result is a sharp drop in English proficiency when students graduate from college.

Although undergraduate courses in the third and fourth grades and college specialties in the second and third grades of professional English teaching, professional English teaching is basically taught by the professional teachers of each school. However, there is no uniform norm for professional English textbooks and teaching methods. Basically, it is taught by the translation method. That is, the relevant professional content written in Chinese is repeated in English. The lecture focuses on reading training, English-Chinese translation, lack of "listening, The simultaneous training of speaking, reading, writing and translating and the cultivation of 
communicative competence can not mobilize the students' ability to use language comprehensively, weaken or lose the opportunity of consolidating and improving basic English after the college students have passed the "examination test". . Some English experts call this phenomenon "professional English and basic English disjunction."

\section{Some ideas for connecting basic English and maritime professional English}

\subsection{The possibility of connecting English between basic English and maritime professional}

The professional English of sailing has its particularity:

1) Professional English is highly professional, embodied in the specialization of words and phrases.

2) "three more", "three less", that is, complex sentences, long words, abbreviations, verb tense changes, less use of rhetoric, less professional vocabulary changes.

However, there are three commonalities between basic English and professional English:

1) Whether you are studying basic English or studying professional English, you must master the pronunciation, vocabulary and grammar of English.

2) Basic English and professional English have a commonality in the application of the ability to apply.

3) Whether basic English or professional English is combined with a certain culture.

Therefore, maritime professional English must also be closely related to and influence each other.

\subsection{Some ideas}

In order to better connect basic English and nautical professional English, we can try to start from the following points:

\subsubsection{Optimize maritime English teacher teachers}

The combination of professional and English has always been the hope of maritime institutions. However, due to the particularity of the maritime profession, there are few teachers who are proficient in both proficiency and proficiency in English. Teachers often present the phenomenon of "one head and one weight". To optimize the faculty of maritime English teachers, we must strive to achieve "professional teachers English, English teachers specialization." So how can we achieve the above requirements? We can try to start from the following points:

The proportion of the instructors is reasonably arranged, that is, the English teachers in the navigation profession are composed of an appropriate proportion of English teachers and marine professional teachers. At the same time, establish and maintain regular exchanges, communication and cooperation between professional English teachers and marine professional teachers to achieve the goal of complementary advantages and common progress.

Optimize the knowledge structure of the instructor. Strengthen English knowledge training for professional teachers. After the class, the "Teaching, Mutual Evaluation and Mutual Help" activities were carried out between professional teachers and English teachers. That is to say, teachers should organize lectures, evaluate each other's classes, and point out the inadequacy of the other class. Through this model, the lecturer's knowledge has been consolidated and sublimated, and the lecturer's knowledge has been expanded and deepened.

\subsubsection{Organic convergence of basic English and nautical English}

Combining the particularity of maritime professional English mentioned above and its commonality with basic English, in the teaching, the basic English teaching as the basic stage must pay attention to the quality and quantity of teaching, help students accumulate enough vocabulary and master the main English word formation. Moreover, in the grammar teaching, we should pay attention to the syntactic structure analysis in the complex sentence, reduce the difficulty of the verb tense, and ignore the learning of English rhetoric. In the basic English teaching, it is necessary to make the students learn the principle of "learning a little, using a little, using a little", so that 
students can lay a solid foundation for learning professional English and master the language skills of using English.

The main reason for the connection between basic English and professional English teaching is the lack of coordination mechanisms and conditions. A more appropriate way to solve this problem is to strengthen communication between basic English teachers, professional English teachers and marine professional teachers. At the same time, teachers are encouraged to adopt English teaching in the teaching of professional courses. Professional teachers are required to intersperse professional words when teaching professional courses. On this basis, it is also possible to further require a competent teacher to teach a course or a chapter. This will not only improve the professional English level of students, but also improve the logical thinking ability of English. Of course, this method is more suitable for some courses with more obvious and descriptive content, such as navigational meteorology, basic knowledge of navigation, and collision avoidance of ships.

\subsubsection{Improve the teaching method of maritime professional English}

Professional English is the transition from basic English to applied English. It is the transformation from reading comprehension to communicative expression, and it is the development of language learning to information exchange. This stage of teaching "is not just teaching English nor simply teaching professional knowledge, but focusing on practical training, so that students can learn how to use English to communicate meaningfully in the professional field." (HGwiddowson, 1974). In order to achieve such a goal, teachers should not only link basic English with professional English knowledge points, but also focus on the ability of basic English and professional English learning, including conversational, reading and translation skills.

In basic English teaching, there are many teaching methods to improve students' interest, such as group discussion, role performance, case analysis, and simulation contact.

In the teaching of maritime professional English teachers, it is also possible to introduce abandoning the traditional translation teaching method and introduce various teaching methods into professional English teaching. Be student-oriented, provide students with more opportunities to participate in interactive learning, and help them improve their professional English memory and presentation skills in repeated use and practice. For example, in the maritime English listening and conversation teaching, the task teaching and the role performance are introduced, and each lecture is regarded as a task, and the students are required to cooperate to complete the task, and then perform the performance on the learned content. Introduce group discussion and simulation exercises in nautical English reading, organize students to discuss the difficulties, and simulate the difficulties. In this way, it can not only enhance students' understanding and memory of knowledge, but also enhance students' interest in learning and exercise their various abilities.

In short, in order to achieve the full and effective connection between maritime professional English and basic English, teachers must clearly define their goals and promote the above three aspects in an orderly and steady manner: improve students' enthusiasm for learning in the basic learning stage, and guide students to carry out corresponding majors. Knowledge reserve; in the professional teaching stage, consciously connect relevant knowledge points, improve students' enthusiasm, bring students into the classroom, increase the intensity of English teaching, and effectively improve students' professional English language application ability.

\section{References}

[1] Yi Minghua. Pay attention to the communication and integration of marine English teaching [J]. Academic Research in Maritime Education, 2002, (2): 47-51.

[2] Widdowson.H.G. "LeingPurposeandLanguageUse" [J]. Oxford University Press, 1984, (6).

[3] Su Bo. Correctly handle the relationship between basic English and professional English teaching [J]. Tianjin Maritime, 2005, (2).

[4] Liu Ling. Pay attention to the art of lectures and enhance the attraction of the classroom [J]. Vocational Technology, 2006, 14, No. 54. 